Инкрустация. Резьба по дереву / А. С. Хворостов. - Москва : Просвещение, 1985. - 176 с. 7. Шорохов Е. В. Основы композиции / Е. В. Шорохов. - Москва : Просвещение, 1979. $223 \mathrm{c}$.

УДК [378:37.011.3-051]:5

Василь Кушнір

\title{
ДО ПРОБЛЕМИ РОЗВИТКУ МЕТОДОЛОГІЧНОЇ КУЛЬТУРИ МАЙБУТНІХ УЧИТЕЛІВ ПРИРОДНИЧИХ ДИСЦИПЛІН У ПРОЦЕСІ ПРОФЕСІЙНОЇ ПІДГОТОВКИ: ВІДГУК НА МОНОГРАФІЧНЕ ДОСЛІДЖЕННЯ
}

Кушнір В. А. До проблеми розвитку методологічної культури майбутніх учителів природничих дисциплін у процесі професійної підготовки: відгук на монографічне дослідження.

У статті розкриваються основні ідеї, наукові підходи, принципи щодо визначення суті й змісту методологічної культури вчителя природничих дисциплін і чинників іiї розвитку в системі професійної підготовки, на підгрунті аналізу монографічного дослідження О. О. Лаврентьєвої.

Ключові слова: методологічна культура вчителя, професійна підготовка вчителя, педагогічні умови, моніторинг процесу розвитку методологічної культури вчителя.

Кушнир В. А. О проблеме развития методологической культуры будущих учителей естественнонаучных дисциплин в процессе профессиональной подготовки: отзыв на монографическое исследование.

В статье раскрываются основные идеи, научные подходы, принципы относительно определения сути и содержания методологической культуры учителя естественнонаучных дисциплин и факторов ее развития в системе профессиональной подготовки на основе анализа монографического исследования Е. А. Лаврентьевой.

Ключевые слова: методологическая культура учителя, профессиональная подготовка учителя, педагогические условия, мониторинг процесса развития методологической культуры учителя.

Kushnir V. A. Concerning the problem of method competence of future teachers in natural sciences in the course of their professional training: review of monographic research.

The main ideas, scientific approaches, the principles concerning the definition of the essence and the content of method competence of teachers in natural sciences are revealed. The factors of method competence development in the course of professional training are considered on the analysis of monographic research of O. O. Lavrentieva.

Key words: method competence of a teacher, teacher's training, pedagogical conditions, monitoring of the teacher's method competence development.

Сучасному вчителю потрібні надпредметні знання високого рівня сформованості, які надали б можливість розв'язувати міжпредметно-системно-інтегративні проблеми, аналізувати й оцінювати нові педагогічні розробки й визначати їх місце у створеній методичній системі, розробляти власні підходи, методики, прийоми використання сучасних засобів навчання, передовсім інформаційно-комунікаційних технологій, визначати зміст власної методичної системи. Тому актуальність монографічного дослідження 
О. Лаврентьєвої «Розвиток методологічної культури майбутніх учителів природничих дисциплін у процесі професійної підготовки: теоретико-методичний аспект» не викликає сумніву.

Метою статті є розкриття основних ідей і результатів монографічного дослідження. Завданнями є виявлення актуальності монографічної праці, теоретичних і практичних здобутків авторки, застосування результатів дослідження в сучасному процесі професійної підготовки майбутніх учителів природничих дисциплін. Предметом дослідження є аналіз теоретичних і практичних здобутків О. Лаврентьєвої, розкриття їх значущості в сучасній українській педагогіці.

У першому розділі монографії авторка досліджує сучасний стан професійної підготовки вчителів природничих дисциплін в Україні, розкриває вплив педагогічних шкіл, статус природничих наук у ціннісних вимірах суспільства. Авторка розкриває суть, зміст і структуру професійної підготовки в таких напрямках: структурно-системний, особистісно зорієнтований, професійно зорієнтований, історико-культурологічний; тлумачить професійну підготовку як поліфункціональну відкриту систему. Під час дослідження розвитку й саморозвитку особистості дослідниця виходить із принципів фундаменталізації, гуманізації, гуманітаризації, стандартизації, багаторівневості, диференціації, комп’ютеризації, індивідуалізації педагогічного процесу й освіти загалом, розкриває їх суть i зміст. Доробком авторки є виокремлення й аналіз специфічних рис професійної підготовки вчителя: професійна соціалізація, фундаментальне засвоєння предмета, формування у студентів цілісної картини педагогічного процесу.

Авторська модель професійної підготовки вчителя відображає іiі структуру, а саме: виокремлюються компоненти: загальнонаукова підготовка, фундаментальна, предметна, психолого-педагогічна, методична, практична, науково-педагогічна, інформаційнотехнологічна. Авторка розкриває суть, зміст, функції наведених компонентів професійної підготовки вчителя, що $\epsilon$ новим науковим результатом у педагогічних дослідженнях, виокремлює три цикли дисциплін: гуманітарної та соціально-економічної підготовки, математичної та природничо-наукової, професійної та практичної; досліджує призначення кожного циклу у професійній підготовці майбутніх учителів. Головним результатом професійної підготовки вчителя авторка вважає професійно-педагогічну культуру вчителя і iї складник - методологічну культуру як цілісне особистісне утворення, а не набір окремих методологічних знань.

Розглядаючи концептуальні проблеми розвитку методологічної культури майбутніх учителів природничих дисциплін, дослідниця виокремила систему ідей, положень, які класифікувала в окремі концепти. Ціннісно-орієнтаційний концепт- це суспільні й індивідуальні орієнтири, ідеальні зразки діяльності особистості, синонім культурноісторичних стандартів, життєвий стиль. Авторка виокремлює систему педагогічних цінностей методологічної культури майбутніх учителів природничих наук як принципи раціональності, детермінізму, відповідності, гуманізму, доповнювальності, інваріантності, еволюціонізму, наступності, системності, цілісності і єдності світу, розвитку, самоорганізації, симетрії, трансляції, дуальності тощо. Гуманістичний концепт у тлумаченні авторки передбачає комплекс механізмів, що зорієнтовані на розкриття особистості, іiі самоактуалізацію, самореалізацію, а гуманізм дослідниця тлумачить як особливий світогляд, центром якого є людина як головна суспільна істота. Компетентнісний концепт в уявленнях дослідниці передбачає поступальний рух від методологічної грамотності, методологічної освіченості, методологічної компетентності до певного рівня методологічної культури як 
цілісного утворення, яка визначає рівень освіченості вчителя, розвиває здатність оцінювати нові концепції навчання природничих дисциплін, оцінювати новітні педагогічні теорії, якісно оцінювати й вибирати підручники й посібники, методи і способи розв'язування навчальних проблем, розвивати світогляд особистості майбутнього вчителя. Культурологічний концепт передбачає інтеріоризовану загальну культуру, що виконує функцію проектування загальної культури у сферу педагогічної діяльності. Системнодіяльнісний концепт передбачає, що розвиток методологічної культури майбутнього вчителя природничих дисциплін повинен відбуватися у спеціально організованій професійній діяльності, де розкривається методологічний аспект професійної діяльності вчителя, коли суб'єкти учіння здобувають не просто окремі методологічні знання, а цілісну їх систему, котра у своєму розвитку перетворюється на методологічну культуру.

У другому розділі дослідниця відзначає, що в дефініціях «методологія» пов'язується 3 учінням про метод, структурою дослідження, його методами, способами й засобами. Аналізуючи категорію «культура», авторка відзначає іiі багатогранність, наводить підходи до розкриття суті i змісту цієї категорії: описовий, опозиційний (культура-натура), аксіологічний, адаптивний, історичний, функціональний, герменевтичний, семіотичний, психологічний, дидактичний.

Поняття «методологічна культура вчителя» О. Лаврентьєва пов'язує з методологічним ставленням суб'єкта до дійсності, методологічною рефлексією, процедурами методологічної діяльності, методологічною редукцією, методологічними засобами, міждисциплінарними дослідженнями, інтегративністю і всебічністю поглядів на світ, цілісного сприймання педагогічних явищ, показниками методологічної культури вчителя (наявність володінням системою наукових знань, вибір методологічної позиції, володіння процедурами методологічного аналізу тощо), особистісним і суспільними цінностями, щяо було прелюдією до більш глибокого й детального аналізу поняття «методологічної культури вчителя» на основі аксіологічного, акмеологічного, конструктивно-діяльнісного, феноменологічного, культурологічного наукових підходів.

Дослідниця обгрунтовує й виокремлює функції методологічної культури вчителя: адаптивна $з$ частковими функціями (пізнавальна, аксіологічна, інформаційно-комунікаційна, нормативна, знакова), інтеграційна, прогностична, креативна, критико-рефлексивна, професійного саморозвитку вчителя. Структура методологічної культури містить ціннісне ядро; провідна загальна функція - світоглядна.

Дослідниця обгрунтовує та вводить власне визначення методологічної культури вчителя в широкому та у вузькому значеннях. О. Лаврентьєва досліджує методологічну культуру вчителя в метасистемі професійно-педагогічної культури вчителя природничих дисциплін. Важливим науковим доробком авторки $\epsilon$ теоретичне обгрунтування й практична реалізація різних моделей типових алгоритмів діяльності вчителя при розв'язуванні методологічної проблемної ситуації.

У третьому розділі О. Лаврентьєва виокремлює позицію, що основними компонентами методологічної культури вчителя є методологічні знання філософського, загальнонаукового, конкретно-наукового й технологічного рівнів. Авторка аналізує з позицій загальної теорії діяльності поняття «методологічна діяльність», виокремлює та характеризує всі їі складники. Для виокремлення елементів методологічної культури вчителя природничих дисциплін авторка виокремила систему принципів: генералізації, фундаментальності, науковості, гуманізації, гуманітаризації, цілісності, додатковості, історизму, розвитку, що $\epsilon$ основою дослідження змісту методичної культури вчителя природничих дисциплін. Складні 
утворення методологічної культури вчителя - методологічна свідомість, методологічна компетентність, детермінанти методологічної діяльності- авторка розглядає як кластерні системи, які вже володіють певними властивостями, що спрощує їх опис, характеризує ці кластери.

Досліджуючи методологічну свідомість, авторка розробляє критерії відбору та класифікує систему наукових методів учителя природничих наук, визначає їх функції, характеристики, класи, рівні застосування. Розкриваючи специфіку методологічної рефлексії, авторка формулює мету, виокремлює об'єкт, предмет, функції, аспекти, спрямованість, модуси, механізми здійснення, засоби активації, особливості виявлення.

Авторка аналізує кластер методологічної компетентності (методологічні вміння, методологічні здібності), подає структуру методологічних умінь у вигляді груп умінь (інтелектуальні, дослідницькі, проектувальні, рефлексивні). У результаті аналізу методологічних здібностей авторка розкриває структуру здібностей учителя природничих наук, визначає види здібностей (інтелектуальні, академічні, дидактичні, організаційні, прогностичні, естетичні, рефлексивні, критичне мислення), виокремлює індикатори кожного виду здібностей.

Досліджуючи кластер індивідуально-гностичних $і$ изінісних детермінант, авторка виокремлює систему наукових і педагогічних цінностей: цінності-цілі, цінності-завдання, цінності-ставлення, цінності-засоби, цінності-якості, розкриває суть кожної цінності. До цього ж кластера О. Лаврентьєва відносить індивідуально-гностичні риси особистості, здійснює їх виокремлення та подає детальні характеристики; виокремлює й досліджує функції в методологічній діяльності (оцінна, регулятивна, прогностична, мобілізаційна).

Здійснюючи системно-морфологічний аналіз структури методологічної культури вчителя природничих дисциплін, дослідниця виокремлює позиції дослідження методологічної культури: методологічна культура має метасистемний характер; є своєрідним підсумком розвитку знань, інтересів, переконань, норм діяльності й поведінки, здібностей і соціальних почуттів учителя; є результатом колективного й суб' єктного виміру особистості; в широкому смислі є культурою педагога-дослідника, у вузькому - окреслює культуру мислення вчителя для розв'язання практичних завдань; визначає особливості професійного мислення, професійних цінностей; є інтегративною цілісністю, що створює добру основу для виділення компонент методологічної культури вчителя природничих дисциплін. Такими компонентами, згідно з думкою авторки, $\epsilon$ : мотиваційно-ціннісний, інтелектуальнокогнітивний, діяльнісно-практичний, творчо-рефлексивний, структурно-критеріальний; науковець характеризує виділені компоненти.

На основі попередніх теоретичних здобутків О. Лаврентьєва створює модель розвитку методологічної культури майбутніх учителів природничих наук у процесі професійної підготовки, що $є$ потрібною ланкою перед розробленням методичної системи розвитку методологічної культури майбутнього вчителя природничих дисциплін, ланкою переходу від теоретичних напрацювань до їх утілення в методичну систему, методику, яка і призначена для реалізації теоретичного доробку на практиці.

Дослідниця розкриває зміст «розвиток» як незворотність змін особистості. Закономірності розвитку описує системою загальних (гуманізації і гуманітаризації, професійної спрямованості, науковості й фундаментальності, індивідуалізації й диференціації, культурної детермінації) $i$ специфічних (логізації, проблемно-методологічного структурування, методичної рефлексії, культуровідповідності, раціогуманізму, методологічної діяльності викладачів і студентів, циклічності, саморозвитку) принципів і 
наукових підходів на стратегічному рівні (культурологічний, гуманістичний, компетентнісний, ціннісно-орієнтаційний, особистісно-діяльнісний) i на тактичному рівні (когнітивний, проблемний, задачний, діалогічний, імітаційно-ігровий, міждисциплінарний, контекстний).

Четвертий розділ дослідниця присвячує створенню методичної системи розвитку методологічної культури майбутнього вчителя природничих наук. Вона обгрунтовує i виокремлює педагогічні умови та створює методику поетапного розвитку досліджуваного феномену в системі професійної підготовки.

Розкриваючи суть і зміст першої умови - готовність викладача до вироблення в майбутніх учителів особливого для сфери освіти стилю мислення, дослідниця стає на позицію, що «готовність» $€$ інтегративною якістю особистості, яка грунтується на професійному мисленні викладача (наукове мислення, методичне, педагогічне), виокремлює у структурі готовності компоненти: особистісна готовність, науково-теоретична, практична. Друга педагогічна умова - посилення наскрізної загальної і спеціальної методологічної підготовки майбутніх учителів - передбачає формування у студентів методологічних понять, оволодіння ними методами наукового дослідження, освоєння методології педагогіки, методологічної грамотності, компетентності. Третя умова- використання механізмів методологічної рефлексії у сприйнятті, розумінні, проектуванні та конструюванні майбутніми вчителями педагогічної реальності- передбачає рефлексію, засновану на системному розумінні та інтеграції різних дисциплін, принципі зворотного зв'язку, самоаналізі, самопізнанні, рефлексивному виході, рефлексивній позиції. Четверта умова педагогічний моніторинг стану методичної системи розвитку методологічної культури майбутнього вчителя природничих дисциплін - передбачає судження про якість професійної підготовки на основі регулярного контролю, проміжних підсумках роботи, аналізу успіхів чи невдач у педагогічній діяльності вчителя, використання математичної статистики.

До методичної системи авторка включає також моніторинг розвитку методологічної культури студентів вищої педагогічної школи, виокремлює й характеризує його чотири основні позиції. У першій позиції розглядає мету, часткові цілі, функції, підсистеми, результат, предмет моніторингу, мотиваційно-ціннісні критерії моніторингу. Друга позиція пов'язана 3 визначенням ступеня сформованості специфічного стилю мислення, третя - 3 рівнем розвитку методологічної культури майбутніх учителів природничих дисциплін (початковий, критичний, достатній, оптимальний), четверта - 3 визначенням рівня готовності викладачів до вироблення у студентів специфічного стилю мислення.

Авторська методика розвитку методологічної культури майбутніх учителів природничих дисциплін у процесі професійної підготовки складається 3 таких етапів: підготовчий, практично-дослідницький, формувальний, розвивальний, контрольнокоригувальний. Дослідниця виокремлює складники: базовий складник професійної підготовки, дослідницько-орієнтовний, практично-орієнтовний, спеціальний складник і в їхньому контексті означає й характеризує засоби розвитку методологічної культури майбутнього вчителя на кожному етапі, зокрема, виокремлює традиційні та інноваційні засоби.

Суттєвими в монографічному дослідженні є додатки, які органічно й системно доповнюють дисертацію, деталізують ті аспекти дослідження, які в основному тексті детально не розкриті. Особливо важливими додатки є для впровадження методичної системи загалом і методики розвитку методологічної культури вчителя природничих дисциплін зокрема на практиці різними викладачами. Цей матеріал може бути основою відповідних 
методичних посібників і рекомендацій.

Монографічне дослідження О. Лаврентьєвої загалом розвиває ідеї, погляди, наукові здобутки праць С. Гончаренка [1], В. Кременя [3], В. Кушніра [4], В. Краєвського [2] та інших щодо вдосконалення змісту професійної освіти, є значним науковим доробком в українській педагогічній науці, буде корисним викладачам природничих та інших дисциплін.

\section{Література}

1. Гончаренко С. Педагогічні дослідження: Методологічні поради молодим науковцям / Семен Устимович Гончаренко. - Київ - Вінниця : ДОВ «Вінниця», 2008. - 278 с. 2. Краевский В. Методология педагогики: новый етап : [учеб. пособие] / В. В. Краевский, Е. В. Бережнова. - Москва : Академия, 2006. - 400 с. 3. Кремень В. Освіта і наука в Україні інноваційні аспекти. Стратегія. Реалізація. Результати / Василь Григорович Кремень. - Київ : Грамота, 2005. - 448 с. 4. Кушнір В. Системний аналіз педагогічного процесу: методологічний аспект: [монографія] / Василь Андрійович Кушнір.- Кіровоград : Видавничий центр КДПУ, 2001. - 348 с.

УДК 378:[37.011.3-051:5]

Олена Лаврентьєва

\section{ФУНДАМЕНТАЛЬНА ПІДГОТОВКА ВЧИТЕЛЯ ПРИРОДНИЧИХ ДИСЦИПЛІН: СТАН, ПРОБЛЕМИ І ТЕНДЕНЦІЇ}

Лаврентьєва О. О. Фундаментальна підготовка вчителя природничих дисциплін: стан, проблеми і тенденції.

У статті розглядаються питання, існуючі підходи до формування змісту професійної підготовки вчителя природничих дисциплін на засадах фундаменталізації; наводяться результати дослідження стану професійної підготовки вчителя природничих дисциплін, виокремлюються проблеми і суперечності в досліджуваній науковій площині.

Ключові слова: професійна підготовка вчителя природничих дисциплін, фундаменталізація, компетентнісний підхід.

Лаврентьева Е. А. Фундаментальная подготовка учителя естественнонаучных дисциплин: состояние, проблемы и тенденции.

В статье рассматриваются вопросы, существующие подходы к формированию содержания профессиональной подготовки учителя естественнонаучных дисциплин на основе фундаментализации; приводятся результаты исследования состояния профессиональной подготовки, выделяются проблемы и противоречия в исследуемой научной плоскости.

Ключевые слова: профессиональная подготовка учителя естественнонаучных дисциплин, фундаментализация, компетентностный подход.

Lavrentieva O. O. Fundamental training of natural sciences teachers: state, problems and tendencies.

The issues, the existing approaches to the formation of the content for professional training process of future teachers in natural sciences on the basis of a fundamentalization are considered. The results of professional training research are given as well as the problems and contradictions in this scientific area are allocated.

Key words: professional training of teachers in natural sciences, fundamentalization, 